\title{
Environmental Exposure to Metals and Bioaccumulation in the Liver of Three Freshwater Species of Turtles from Two Different Rivers
}

\author{
Zaib-Un-Nisa ${ }^{1,2}$, Salma Sultana ${ }^{1}$, Tayyba Sultana ${ }^{1}$, K. A. Al-Ghanim ${ }^{3}$, \\ Meshal K. Al-Ghanem ${ }^{4}$, F. Al-Misned ${ }^{4}$, Shahid Mahboob ${ }^{1,3 *}$ \\ ${ }^{1}$ Department of Zoology, Government College, University, Faisalabad, Pakistan \\ ${ }^{2}$ Department of Environmental Sciences and Engineering, Faculty of Science, Government College, \\ University, Faisalabad, Pakistan \\ ${ }^{3}$ Department of Zoology, College of Science, King Saud University, Riyadh, Saudi Arabia \\ ${ }^{4}$ Department of Pharmacology and Toxicology, College of Pharmacy, \\ King Saud University, Riyadh, Saudi Arabia
}

Received: 22 March 2018

Accepted: 6 May 2018

\begin{abstract}
Exposure to metals remains an important public health concern. The present study is a comprehensive field study to determine the concentrations of $\mathrm{Cu}, \mathrm{Zn}, \mathrm{Ni}, \mathrm{Cd}, \mathrm{Co}, \mathrm{Pb}$ and $\mathrm{Cr}$ in water samples and in the livers of deceased freshwater turtles collected from pre-determined sampling sites of the Ravi and Chenab rivers. In total, 35 deceased freshwater turtles were collected from the sampling sites, and liver samples were collected and immediately stored at $-20^{\circ} \mathrm{C}$ prior to analysis. Heavy metals concentrations of $\mathrm{Cu}, \mathrm{Zn}$ and $\mathrm{Cd}\left(0.073,0.169\right.$ and $\left.0.0042 \mathrm{mg} / \mathrm{L}^{-1}\right)$ in water samples were collected from the Ravi and $\left(0.084,0.145\right.$ and $\left.0.0041 \mathrm{mg} / \mathrm{L}^{-1}\right)$ from the Chenab. Concentrations of $\mathrm{Ni}, \mathrm{Co}, \mathrm{Pb}$ and $\mathrm{Cr}$ were significantly lower $\left(0.045,0.018,0.06\right.$ and $\left.0.121 \mathrm{mg} / \mathrm{L}^{-1}\right)$ in the Ravi while $(0.045,0.018,0.064$ and $\left.0.121 \mathrm{mg} / \mathrm{L}^{-1}\right)$ in the Chenab were significantly higher. Species-wise mean concentrations of all heavy metals were non-significant $(\mathrm{P}>0.05)$. The mean concentrations of $\mathrm{Cu}$ and $\mathrm{Ni}$ varied significantly $(\mathrm{P}<0.01)$ in the liver samples from the Ravi and Chenab. Regardless of the sampling sites, the mean concentrations of $\mathrm{Cu}$ and $\mathrm{Pb}$ recorded a maximum in $K$. Smithi $\left(26.54 \pm 4.53\right.$ and $3.85 \pm 0.43 \mathrm{mg} / \mathrm{Kg}^{-1}$, respectively) $\mathrm{Zn}$ in $\mathrm{K}$. Tecta $\left(42.48 \pm 4.06 \mathrm{mg} / \mathrm{Kg}^{-1}\right)$ and $\mathrm{Ni}, \mathrm{Cd}$ and $\mathrm{Co}$ in L. Punctata. Among the studied metals, $\mathrm{Zn}$ was recorded as most abundant $\left(39.73 \pm 2.28 \mathrm{mg} \mathrm{Kg}^{-1}\right)$ and $\mathrm{Cd}$ concentration was found to be minimum $\left(0.188 \pm 0.017 \mathrm{mg} \mathrm{Kg}^{-1}\right)$ in freshwater turtles collected from both sampling sites.
\end{abstract}

Keywords: Ravi River, Chenab River, contamination, freshwater turtle, liver; metals

*e-mail: shahidmahboob60@hotmail.com 


\section{Introduction}

Metal contamination of land and water resources and related human health risks remains a major concern worldwide [1-3]. Heavy metals, including both essential and non-essential elements, are important in ecotoxicology [3] due to their toxicity, bioaccumulation, and bio-magnification in the aquatic ecosystem. Some metals are considered essential or beneficial and are necessary for daily nutrition and physiology [4-5]. Other metals, such as $\mathrm{Pb}, \mathrm{Hg}, \mathrm{Cd}$ and $\mathrm{As}$, are non-essential and can be considered potentially toxic xenobiotic substances. Numerous studies have reported on the bioaccumulation of metals in aquatic organisms in the food chain [6-10]. The contamination of aquatic resources has been hypothesized as a major cause for the decrease in populations of aquatic organisms [11-12]. The trace metal bioaccumulation can be found in fish, turtle, etc. The estimation of the level of these metals in long-living animals, like turtles, may be helpful in the monitoring of the reservoir water quality.

Freshwater turtles are vulnerable to late sexual maturity, low fecundity, and high juvenile mortality due to increased anthropogenic impacts in freshwater bodies and its extremities. Few species of turtles are under serious threat in Pakistan due to the lack of proper freshwater reservoir monitoring [13-16]. The contamination of freshwater reservoirs recently has a major threat and has caused a loss to the population of turtles [16-19]. Eight species of freshwater turtles belonging to two families, Geoemydidae and Trionychidae, are recorded from major rivers of the province of the Punjab, Pakistan [20]. A few ecotoxicological studies have been reported on these freshwater turtles, which have a few advantages as a model organism in monitoring the impact of water pollution compared to many other species. Freshwater turtles are extensively available in major water bodies in Pakistan. Turtles are useful for long-term trends of water pollution due to their long life spans [21-23]. A tremendous increase in human population and urbanization in Pakistan and un-planned industries in the urban areas has resulted in the discharge of untreated industrial and domestic wastes, containing different contaminants through runoff into the Ravi and Chenab rivers [24-25]. These pollutants in the Ravi and Chenab have adversely affected the aquatic fauna and flora and impaired the growth rate of aquatic animals [24-25].

Currently, there is a lack of information regarding metal concentrations and exposure risks to freshwater turtles in the river system. The objective of this study was to measure the concentrations of selected heavy metals $(\mathrm{Cu}, \mathrm{Zn}, \mathrm{Ni}, \mathrm{Cd}, \mathrm{Co}, \mathrm{Pb}$ and $\mathrm{Cr})$ in water and their bioaccumulation in the liver of deceased freshwater turtles collected from Balloki Headworks and Trimmu Barrage in Punjab. The information may be helpful for the environmental monitoring agency to suggest measures to ensure a safe supply of fish for consumption in the human community.

\section{Materials and Methods}

\section{Study Area}

The pre-determined sampling sites Trimmu Barrage (TB) and Balloki Headworks (BH) were selected from the Chenab and Ravi, respectively (Fig. 1), based on the reported information [24-25].

\section{Sample Collection}

A total of 35 deceased freshwater turtles were collected in this study from the selected sites. Many of the turtles were eaten by predators (such as dogs) and their body organs were damaged. All freshwater turtle species collected from $\mathrm{BH}$ and $\mathrm{TH}$ were identified and their sizes were measured (Table 1). The liver samples were collected after dissection of dead turtles. Liver tissue samples were prepared by the following method of [26]. The concentrations of $\mathrm{Cd}, \mathrm{Co}, \mathrm{Cu}, \mathrm{Cr}$, $\mathrm{Pb}, \mathrm{Ni}$, and $\mathrm{Zn}$ were estimated in the liver samples by atomic absorption spectrometry (Aurora AAS, Al-1200, Canada) by following the analytical procedure mentioned in AOAC [27].

\section{Statistical Analysis}

The data thus obtained were statistically analyzed by one-way analysis of variance to find the accumulation differences of heavy metal in the liver samples of freshwater turtles collected from different locations. Means were compared with the help of Duncan's Multiple Range Test $(\mathrm{P}<0.05)$.

\section{Results and Discussion}

Heavy metals concentration in water samples of $\mathrm{Cu}, \mathrm{Zn}$ and $\mathrm{Cd}(0.073 \pm 0.06,0.169 \pm 0.0248$ and $\left.0.0042 \pm 0.0005 \mathrm{mg} / \mathrm{L}^{-1}\right)$ collected from the Ravi and $\left(0.084 \pm 0.0074, \quad 0.145 \pm 0.024\right.$ and $\left.0.0041 \pm 0.0005 \mathrm{mg} / \mathrm{L}^{-1}\right)$ in water samples from the Chenab. The concentrations of $\mathrm{Ni}, \mathrm{Co}, \mathrm{Pb}$, and $\mathrm{Cr}$ were significantly lower $\begin{array}{lll}(0.045 \pm 0.0044, & 0.018 \pm 0.0034, & 0.06 \pm 0.004\end{array}$ and $\left.0.121 \pm 0.0066 \mathrm{mg} / \mathrm{L}^{-1}\right)$ in the Ravi and $(0.05 \pm 0.0049, \quad 0.026 \pm 0.0031, \quad 0.056 \pm 0.0043 \quad$ and $\left.0.127 \pm 0.0064 \mathrm{mg} / \mathrm{L}^{-1}\right)$ significantly higher in the Chenab (Table 2). The mean concentrations of $\mathrm{Cu}, \mathrm{Zn}, \mathrm{Cd}$ and Co in the water samples from both rivers was lower than the permissible limits, as suggested by [28], whereas the concentrations of $\mathrm{Pb}$ and $\mathrm{Cr}$ in the water samples from both rivers was higher than the permissible limits, as suggested by [28]. The increase in the concentrations of $\mathrm{Ni}, \mathrm{Co}, \mathrm{Pb}$ and $\mathrm{Cr}$ in the water samples of both rivers and the content of these metals in the liver of deceased 
a)

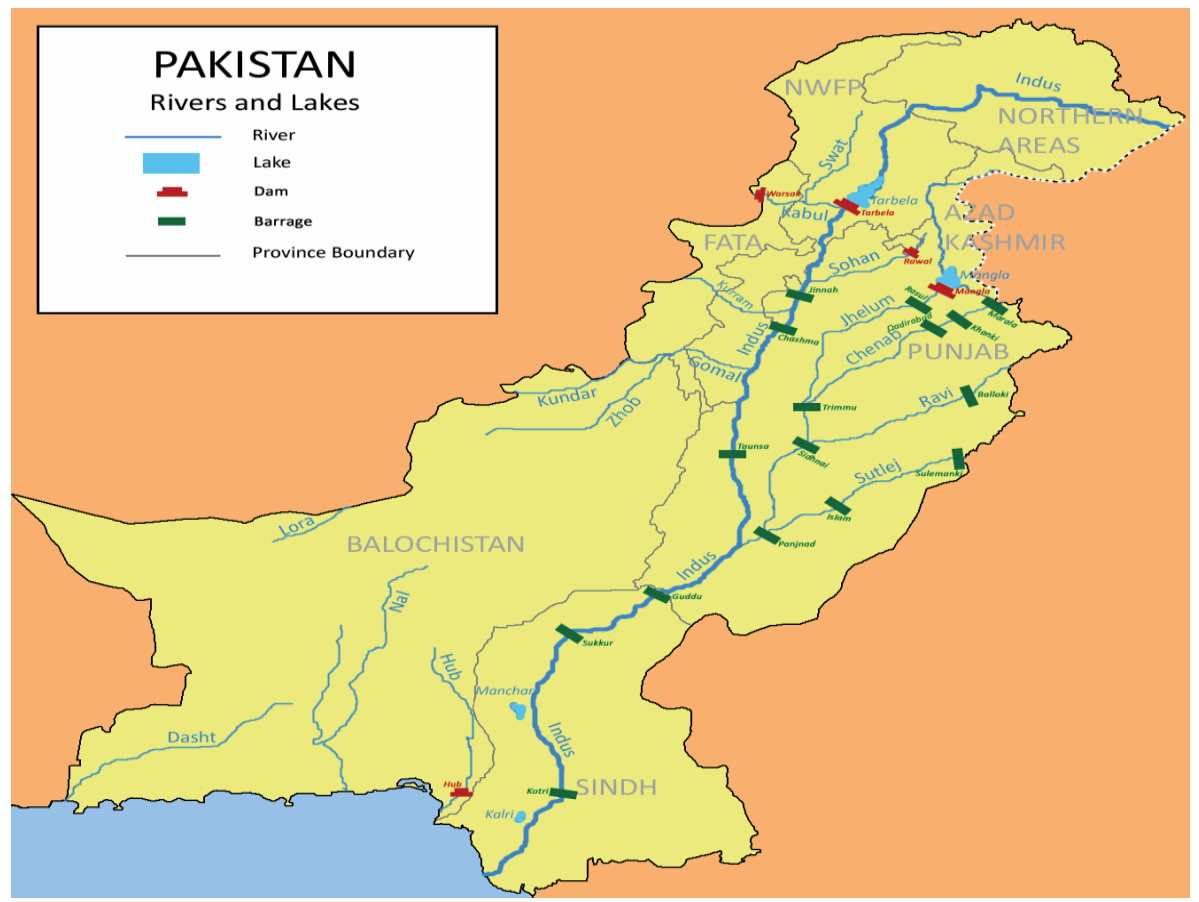

b)

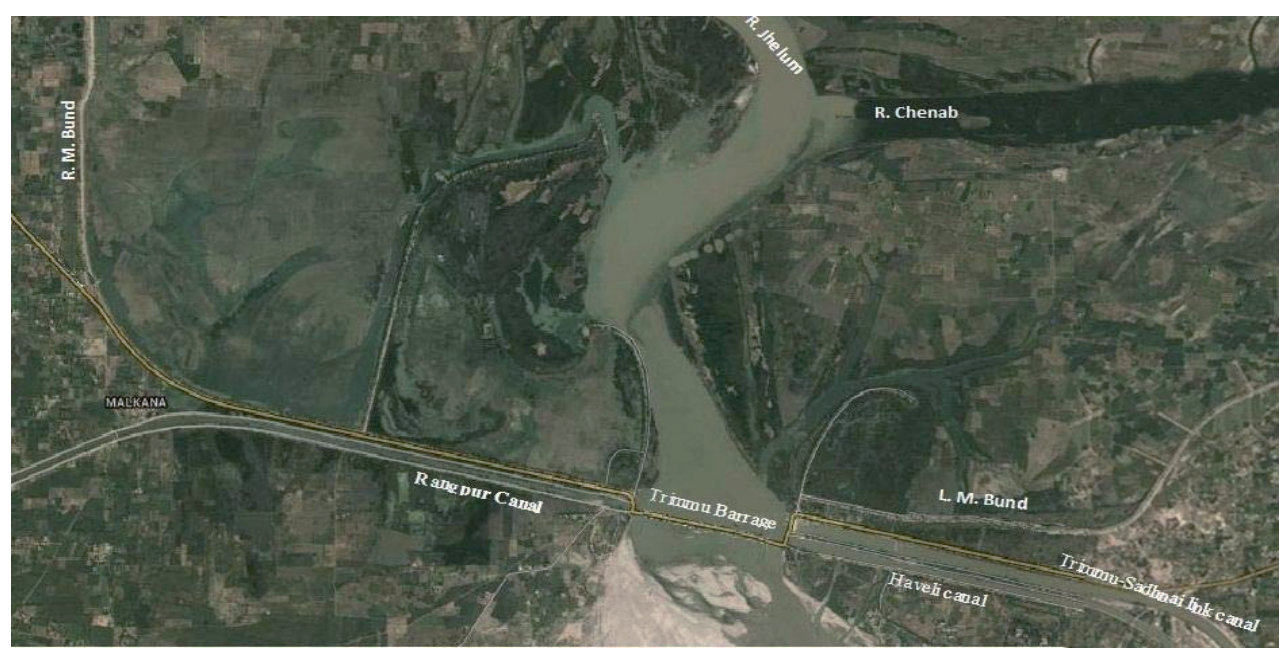

c)

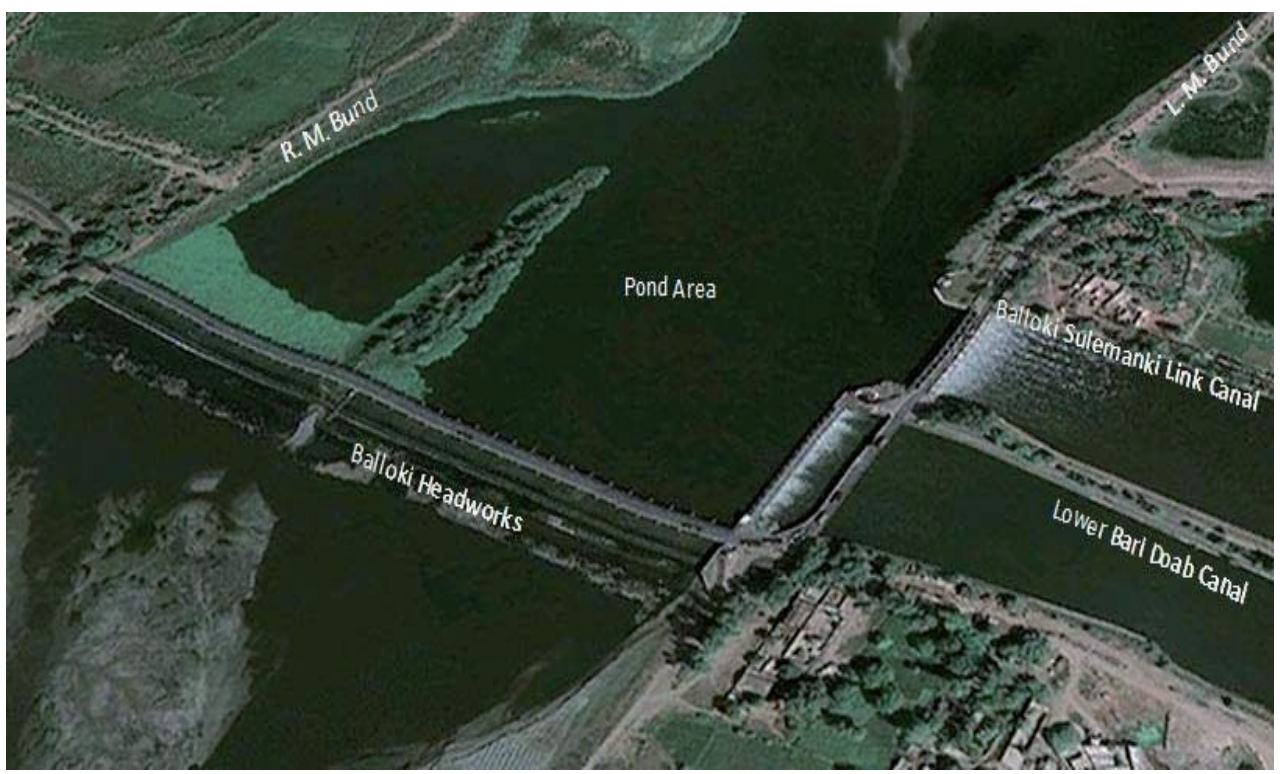

Fig. 1. a) water storage reservoirs and barrages of Pakistan,b) satellite image of Trimmu Headworks,c) satellite image of Balloki Headworks. 
Table 1. Comparison of means for size $(\mathrm{cm})$ between deceased freshwater turtles of Balloki Headworks $(\mathrm{BH})$ and Trimmu Barrage (TB).

\begin{tabular}{|c|c|c|c|c|}
\hline Parameters & $\mathrm{N}$ & Mean \pm SE & t-value & Prob. \\
\hline $\begin{array}{c}\text { Size of dead } \\
\text { freshwater turtles of } \\
\text { Balloki Headworks }\end{array}$ & 15 & $303.18 \pm 34.49$ & & \\
\hline $\begin{array}{c}\text { Size of dead } \\
\text { freshwater turtles } \\
\text { of Trimmu Barrage }\end{array}$ & 20 & $276.14 \pm 29.87$ & 0.59 & 0.557 \\
\hline
\end{tabular}

NS = nonsignificant $(\mathrm{P}>0.05) ; *=$ Significant $(\mathrm{P}<0.05)$;

$* *=$ Highly significant $(\mathrm{P}<0.01)$

$\mathrm{N}=$ Number of observations;

Prob. $=$ Probability

freshwater turtles exhibited a positive relationship. It was due to the discharge of untreated waste from the local industries of paint, dyeing and some food processing industries in the adjacent areas. The highest concentration of these metals in the water samples of the Ravi and Chenab and in the liver is high enough to warrant concern for human consumption of turtles and fish species from these locations.

The 35 deceased freshwater turtles belonging to three species (i.e., Kachuga Smithi, K. Tecta and Lissemys Punctata) were collected from Balloki Headworks (BH) and Trimmu Barrage (TB). Among the samples, 15 were collected from BH (K. Smithi; 4, K. Tecta; 4 and Lissemys Punctata; 7) and 20 from Trimmu Barrage (TB) (K. Smithi; 7, K. tecta; 10 and Lissemys punctata; 3). The differences in the size of freshwater turtles procured from both locations were insignificant (Table 1). Bioaccumulation of heavy metals was studied species-wise, location-wise and sorption trend of metals regardless of species and locations. The interaction of location and species is also clearly studied (Tables 2 and 3). The location-wise mean concentration of $\mathrm{Cu}$ and $\mathrm{Ni}$ varied highly $(\mathrm{P}<0.01)$ as compared to the other five heavy metals with non-significant variation in relation to localities. Mean maximum concentration of $\mathrm{Cu}\left(20.15 \pm 2.66 \mathrm{mg} \mathrm{Kg}^{-1}\right)$ was found in the liver of freshwater turtles from $\mathrm{TB}$, while $\mathrm{Ni}$ in the liver of turtles collected from $\mathrm{BH}$ was $2.92 \pm 0.39 \mathrm{mg} \mathrm{Kg}^{-1}$. Regardless of locality and species, the overall mean of heavy metals concentration in livers of freshwater turtles was recorded in the order $\mathrm{Zn}>\mathrm{Cu}>\mathrm{Cr}>\mathrm{Pb}>\mathrm{Co}>\mathrm{Ni}>\mathrm{Cd}$ (Tables 2 and 3). Mean Maximum concentration of $\mathrm{Zn}$ was found in the liver of freshwater turtles at TB than at $\mathrm{BH}\left(42.13 \pm 3.62,37.19 \pm 2.68 \mathrm{mg} \mathrm{Kg}^{-1}\right.$, respectively).

The mean concentrations of heavy metals studied among the three species of turtle were insignificant $(\mathrm{P}>0.05)$. Maximum and mean concentrations of $\mathrm{Cu}$ and $\mathrm{Pb}$ were found in liver of $K$. smithi $(26.54 \pm 4.53$ and $4.29 \pm 0.51 \mathrm{mg} \mathrm{Kg}{ }^{-1}$, respectively). Mean concentrations of $\mathrm{Zn}$ were recorded as $41.71 \pm 4.71$ and $42.48 \pm 4.06 \mathrm{mg}$ $\mathrm{Kg}^{-1}$ in $K$. smithi and $K$. tecta, respectively, which were higher than in L. punctata. Cadmium, Ni, Co, and $\mathrm{Cr}$

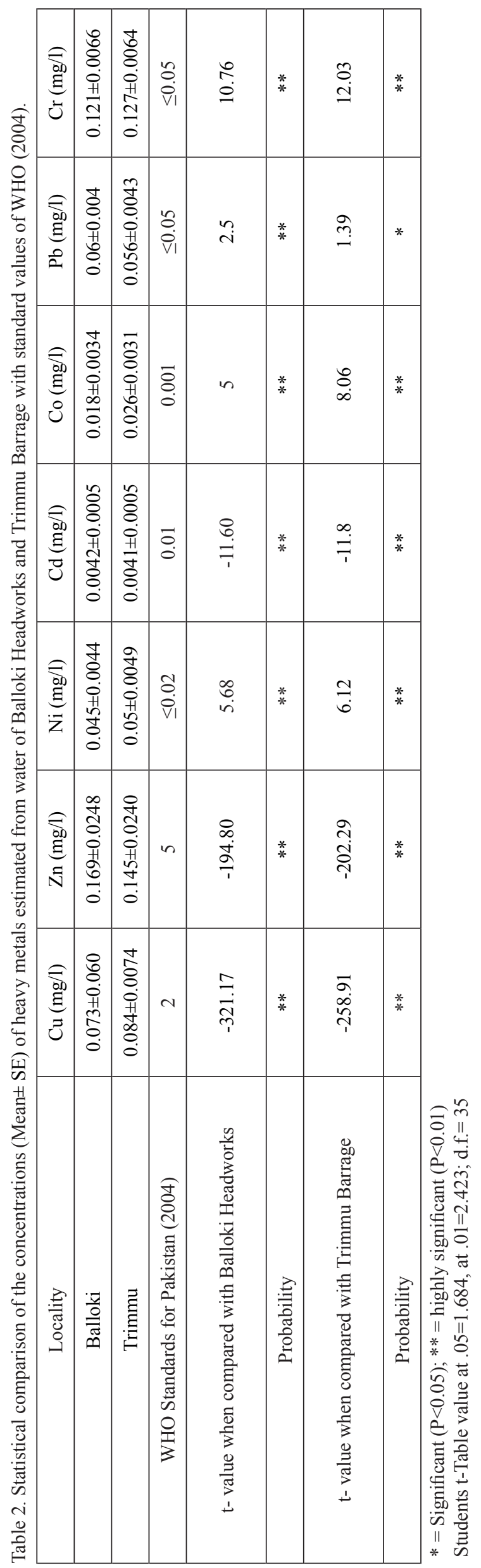



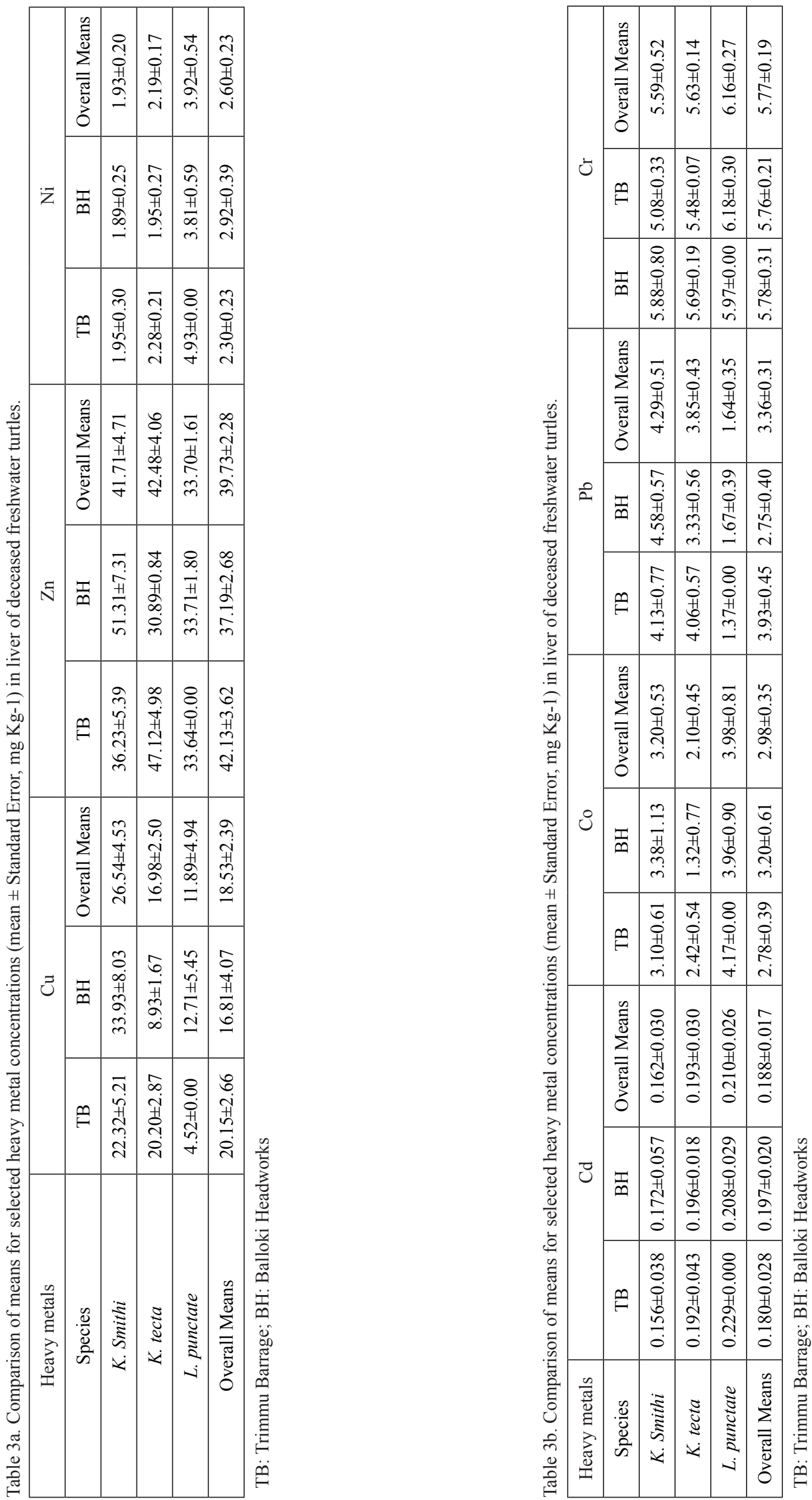
showed greater accumulation in L. punctata. None of the heavy metals showed noticeable higher accumulation in $K$. tecta. The mean concentration of $\mathrm{Pb}$ and $\mathrm{Cr}$ was higher in turtles collected from TB compared to $\mathrm{BH}$. On the other hand, $\mathrm{Cd}\left(0.197 \pm 0.02 \mathrm{mg} \mathrm{Kg}^{-1}\right)$ and $\mathrm{Co}$ $\left(3.20 \pm 0.61 \mathrm{mg} \mathrm{Kg}^{-1}\right)$ concentrations were higher in the liver of turtles from $\mathrm{BH}$.

The results clearly showed the differences between heavy metal bioaccumulation in freshwater turtle species-wise and locality-wise. Among the species', the role of shell composition and structure is noticeable. $L$. punctata has more tendencies to absorb heavy metals than $K$. tecta and $K$. simithi turtles. Both sites are contaminated by untreated agricultural and industrial effluents from point and non-point sources. Trimmu Barrage (TB) receives effluents from sugar cane mills, the textile sector, rice mills, agricultural zones and multiple small and commercial, industrial units near and around Jhang, Jehalum and Chenab cities. Balloki Headworks (BH) receives polluted water of Lahore, Sialkot and Faisalabad cities. One thing is in common with $\mathrm{BH}$ and $\mathrm{TB}$ in that both receive water from the Chenab, which gets mixed with the Ravi River at Balloki and the Jehlum River at Trimmu [29]. Metals from polluted water move to an organism's body and accumulate in various organs according to accumulation preferences. Other factors, like difference at species level, gender, age, location, seasonal variation, etc., also affect toxicity and accumulation levels in organisms [30]. In the present study, $\mathrm{Cu}$ concentrations in the liver of freshwater turtles from $\mathrm{BH}(16.81 \pm 4.07)$ were similar to Ganges turtles from Rasul Barrage (16.24 \pm 2.54$)$ and dissimilar to Ganges turtles from $\mathrm{BH}(21.23 \pm 2.36)$. In comparison, in the present study $\mathrm{Cu}$ concentrations in the liver of the soft shell turtle L. punctata from BH $\left(12.71 \pm 5.45 \mathrm{mg} \mathrm{kg}^{-1}\right)$ were much lower than those found in Ganges softshell turtles $(21.23 \pm 2.36)[2,31]$. Zinc is an essential element for reproduction; it accumulates in the bones and carapace from the blood [32-33]. The present findings for $\mathrm{Zn}$ are upheld by [32], who estimated the concentration of zinc $(38.63 \pm 3.53)$ in the liver of freshwater turtles (Aspideretes gangeticus) from $\mathrm{BH}$. The current reported values for $\mathrm{Ni}$ concentrations in turtles from both sites are greater than the findings of [33]. The noticeable dissimilarities in the concentrations of $\mathrm{Ni}$ may be due to the variations in the level of contamination, environment, and metabolic processes associated with turtle species and with their habitat [30]. [33] No turtles had Cd greater than the minimum detection limit in the liver, while in the present study, a considerable concentration of $\mathrm{Cd}$ was detected in the liver of L. punctata at both localities. The environmental $\mathrm{Cd}$ level (i.e., $1 \mu \mathrm{g} \mathrm{g}^{-1}$ ) may influence the gonadal development in Trachemys scripta during the postnatal and embryonic stages. The higher concentration of $\mathrm{Cd}$ may impair reproductive processes later in life [34]. Among the three species of freshwater turtles, higher concentrations of Co were detected in $L$. punctata compared to the other two species. One strong reason behind this difference may be its soft shell, which may effectively pass on Co to liver by absorption. A higher concentration of Co $(2.78 \pm 0.39$ and $3.20 \pm 0.61$ $\mathrm{mg} \mathrm{Kg}$ ) in the liver of turtles was recorded from TB and $\mathrm{BH}$, respectively. Our findings were in line with the results reported in green turtles by $[2,32]$ from Yaeyama Islands, Japan. In this study the level of $\mathrm{Pb}$ in the liver of freshwater turtles was similar to Olive Ridley turtles (3.32 $\mu \mathrm{g} / \mathrm{g})$ in Mexico [35]. The results of the present study were also in line with [36], who reported higher $\mathrm{Pb}$ concentrations of $2.75 \mu \mathrm{g} / \mathrm{g}$ in the liver of Loggerhead turtles from southwestern Mediterranean, Spain.

$\mathrm{Cr}$ is an essential element to organisms for carbohydrate metabolism in trace amounts [36]. However, $\mathrm{Cr}$ intoxication damages the liver [31]. The concentration of $\mathrm{Cr}$ in the present study was quite higher than in Aspideretes gangeticus (0.39 $\mu \mathrm{g} / \mathrm{g})$ from two barrages, i.e., BH and Rasul [37-38]. [33] also reported a maximum accumulation of $\mathrm{Cr}$ in the liver $(3.32 \pm 0.559)$ than in other organs, though this concentration of $\mathrm{Cr}$ is less in the freshwater turtles from $\mathrm{BH} \quad\left(5.78 \pm 0.31 \mathrm{mg} \mathrm{Kg}^{-1}\right)$ and $\mathrm{TB}$ $\left(5.76 \pm 0.21 \mathrm{mg} \mathrm{Kg}^{-1}\right)$. Information on the toxicity of $\mathrm{Cd}$ on reptiles is insufficient, so predicting the consequences of the detected $\mathrm{Cd}$ residues on three freshwater species of turtle population health is presently not possible. The accumulation of higher concentrations of metals in the liver of these freshwater species of turtles indicates the pervasiveness in these rivers, and its accumulation up in the food chain [38]. The reptile population throughout the world is currently under threat because of increasing levels of contamination in the freshwater ecosystem, and there is a dire need to determine the level of contamination and potential risk to the turtle population [38].

\section{Conclusion}

The overall mean concentrations of $\mathrm{Cu}, \mathrm{Zn}, \mathrm{Ni}$, $\mathrm{Cd}$, and $\mathrm{Cr}$ were high in L. punctata as compared to $K$. smithi and $K$. tecta. The mean concentrations of Co and $\mathrm{Pb}$ were high in $K$. tecta and $K$. Smithi, respectively. Locality-wise the mean concentrations of $\mathrm{Cu}$ and $\mathrm{Pb}$ were high in freshwater turtles at Trimmu Barrage, while the mean concentrations of $\mathrm{Zn}, \mathrm{Ni}, \mathrm{Cd}, \mathrm{Co}$, and $\mathrm{Cr}$ were high in freshwater turtles at Balloki Headwork. There are chances of heavy metals biomagnifications in top consumers, resulting in serious health hazards. It is the need of time that more research work shall be continued, and law-enforcement agencies collectively should come forward to save the populations of freshwater turtles.

\section{Acknowledgements}

The authors would like to express their sincere appreciation to the Deanship of Scientific Research at 
King Saud University for its funding of this research through the Research Group Project No. Prolific Research Group No. 1436-011.

\section{Conflict of Interest}

The Authors declare no conflict of interest.

\section{Ethical Guidelines}

The standard guidelines for animal experiments prepared by the department and the university were followed in this study.

\section{References}

1. MACHADO A.A.S., SPENCER K., KLOASAE W., TOFFOLON M., ZAR C. Metal fate and effects in estuaries: A review and conceptual model for better understanding of toxicity. Science of The Total Environment 541, 268, 2016.

2. BAQAR M., SADAF Y., AHMAD S.R. MAHMOOD A., LI J., ZHANG G. Organochlorine pesticides across the tributaries of River Ravi, Pakistan: Human health risk assessment through dermal exposure, ecological risks, source fingerprints and spatio-temporal distribution. Science of the Total Environment 618, 291, 2018.

3. LARA N.R.F., MARUES T.S., MONTELO K.M., de ATAIDES Á.G., VERDADE L.M., MALVASIO A., de CAMARGO P.B. A trophic study of the sympatric Amazonian freshwater turtles Podocnemis unifilis and Podocnemis expansa (Testudines, Podocnemidae) using carbon and nitrogen stable isotope analyses. Canadian Journal of Zoology, 90 (12), 1394, 2012.

4. EL-KARIM M.S.A., GOHER M.E. Heavy Metal Concentrations in Cyanobacterial Mats and Underlying Sediments in Some Northern Western Desert Lakes of Egypt. Journal of Fisheries and Aquatic Science, 11, 163, 2016.

5. MOHIUDDIN K.M., ZAKIR H.M., OTOMO K., SHARMIN S., SHIKAZONON N. Geochemical distribution of trace metal pollutants in water and sediments of downstream of an urban river. International Journal of Environmental Science and Technology, 7, 17, 2010.

6. BANDOWE B.A., BIGALKE M., BOAMAH L., NVARKO E., SAALIA F.K., WILCKE W. Polycyclic aromatic compounds (PAHs and oxygenated PAHs) and trace metals in fish species from Ghana (West Africa): bioaccumulation and health risk assessment. Environment International, 65, 135, 2014.

7. VELUSAMY P., PITCHAIMUTHU S., RAJALKAKSHMI S., KANNAN N. Modification of the photocatalytic activity of $\mathrm{TiO}_{2}$ by $\beta$-cyclodextrin in decoloration of Ethyl Violet dye. Journal of Advances Research, 5 (1), 19, 2014.

8. BO M., BAVESRRELLO G., ANGIOLILLO M., CALCAGNILE L., CANESE C.S., CNNAS R., CAU A., D'ELIA M., D'ORIANO F., CRISTINA M., GIANLUCA F, QUARTA G., CAUU Q.A. Persistence of Pristine
Deep-Sea Coral Gardens in the Mediterranean Sea (SW Sardinia). PLoS ONE 10 (3), e0119393. https://doi. org/10.1371/journal.pone.0119393, 2015.

9. MONIKH F.A., SAFAHEIEH A., SAVARI A., DORAGHI A. Heavy metal concentration in sediment- benthicbenthopelagic, and pelagic fish species from Musa Estuary: Persian Gulf. Environmental Monitoring Assessment, 185, $215,2013$.

10. ZHANG X., ZHANG T., LIU L., OUYANG X. Impact of Soil Heavy Metal Pollution on Food Safety in China. PLoS ONE 10(8): e0135182. https://doi.org/10.1371/journal. pone. $0135182,2015$.

11. NAMROODI S., ZACCARONI A., REZAEI H., HOSSEIN S.M. European pond turtle (Emys orbicularis persica) as a biomarker of environmental pollution in Golestan and Mazandaran provinces, Iran. Veterinary Research Forum 8 (4), 333, 2017.

12. ROUZBAHANI M.M. Heavy metal concentrations in different tissues of Euryglossa orientalis, Chirocentrus nudus and sediments in Bahrekan Bay (the northwest of Persian Gulf). Iranian Journal of Fisheries Sciences 16 (3), 945, 2017.

13. NISA Z.U. Freshwater turtles as indicator of environmental pollution by estimation of heavy metals at Trimmu Barrage and Balloki Barrage. PHD thesis Department of Zoology, Government College University, Faisalabad, Pakistan, 2013.

14. GURLET E., DAS K. Cadmium toxicokinetics and bioaccumulation in turtles: trophic exposure of Trachemys scripta elegans. Ecotoxicology, 21, 18, 2012.

15. TURNQUIST M.A., DRISCOLL C.T., SCHULZ K.L., SCHLAEPFER M.A. Mercury concentrations in snapping turtles (Chelydra serpentina) correlate with environmental and landscape characteristics. Ecotoxicology, 20 (7), 1599, 2011.

16. MARQUEZ-FERRANDO R., SANTOS X., PLEGUEZUELOS J.M., ONTIVEROS D. Bioaccumulation of heavy metals in the lizard Psammodromus algirus after a tailing-dam collapse in Aznalcollar (Southwest Spain). Archives Environmental Contamination and Toxicology, 56, 276, 2009.

17. SHERWOOD N.R. Risks Associated with Harvesting and Human Consumption of Two Turtle Species in New Jersey. $\mathrm{PhD}$ thesis Montclair State University Upper Montclair, NJ. 263, 2017.

18. United Nations Environment Programme Global Mercury Assessment, Sources, Emissions, Releases and Environmental Transport. Source:http://www.unep. org/chemicalsandwaste/Mercury/Informationmaterials/ Reports and Publications/tabid/3593/Default.aspx, 2013.

19. Turtle Conservation Coalition. RHODIN A.G.J., WALDE A.D., HORNE B.D., VAN DIJK P.P., BLANCK T., HUDSON R. (Eds.)]. Turtles in Trouble: The World's 25+ Most Endangered Tortoises and Freshwater Turtles 2011. Lunenburg, MA: IUCN/SSC

20. ZAIB U.N., SULTANA S., SULTANA T., JABEEN F. Accumulation of heavy metals $(\mathrm{Cu}, \mathrm{Zn}, \mathrm{Ni}, \mathrm{Cd}, \mathrm{Co}, \mathrm{Pb}$ and $\mathrm{Cr}$ ) in blood of freshwater turtles from Balloki headworks and Trimmu barrage, Punjab, Pakistan. Pure and Applied Biology, 4, 280, 2015.

21. HOPKINS W.A., BODINOF C., BUDISCHAK S., PERKINS S. Nondestructive indices of mercury exposure in three species of turtles occupying different trophic niches downstream from a former chloralkali facility. Ecotoxicology, 22, 22, 2013. 
22. CHON H.S., OHANDIA D.G., VOULVOULIS N. The role of sediments as a source of metals in river catchments. Chemosphere, 88, 1250, 2012.

23. BISHOP B.E., SAVITZKY B.A., ABDEL-FATTAH T. Lead bioaccumulation in emydid turtles of an urban lake and its relationship to shell disease. Ecotoxicology and Environmental Safety, 73 (4), 565, 2010.

24. MAHBOOB S., NIAZI F., AL-GHANIM K., SULTANA S., AL-MISNED F., AHMED Z. Health risks associated with pesticide residues in water, sediments and the muscle tissues of Catla catla at Head Balloki on the River Ravi. Environmental Monitoring and Assessment 187: 81. https://doi.org/10.1007/s10661-0154285-0, 2015.

25. HUSSAIN B., SULTANA S., SULTANA T., MAHBOOB $\mathrm{S}$, AL-GHANIM K.A., NADEEM S. Variation in genotoxic susceptibility and biomarker responses in Cirrhinus mrigala and Catla catla from different ecological niches of the River Chenab. Environmental Science and Pollution Research Journal, 23 (14), 14589, https://doi.org/10.1007/s11356-016-6645-x, 2016.

26. PAEZ-OSUNA F., CALDERON-CAMPUZANO M.F., SOTO-JIMENEZ M.F., RUELAS-INZUNZA J.R. Trace metals $(\mathrm{Cd}, \mathrm{Cu}, \mathrm{Ni}$, and $\mathrm{Zn})$ in blood and eggs of the sea turtle Lepidochelys olivacea from a nesting colony of Oaxaca, Mexico. Archives Environmental Contamination and Toxicology, 59, 632, 2010.

27. AOAC. Official Methods of Analysis Association of Official Analytical Chemists. Arlington, VA, USA, 1990.

28. WHO. Guidelines for Drinking Water Quality, $3^{\text {rd }}$ edition., 2004.

29. TABINDA A.B., BASHIR S., YASIR A., HUSSAIN M. Metals concentrations in the riverine water, sediments and fishes from river Ravi at Balloki Headworks. The Journal of Animal \& Plant Sciences, 23, 76, 2013.

30. ZHANG L., CAMPBELL L.M., JOHNSON T.B. Seasonal variation in mercury and food web biomagnification in
Lake Ontario, Canada. Environmental Pollution, 161, 178, 2012.

31. ANAN Y., KUNITO T., WATANABE I., SAKAI H., TANABE S. Trace element accumulation in hawksbill turtles (Ertmochelys imbricata) and green turtles (Chelonia mydas) from Yaeyama islands, Japan. Environmental Toxicological Chemistry, 20, 2802, 2011.

32. BERGERON C.M., HOPKINS W.A., TODD B.D., HEPNER M.J., UNRINE J.M. Interactive effects of maternal and dietary mercury exposure have latent and lethal consequences for amphibian larvae. Environmental Science Technology, 45, 3781, 2011.

33. YU S., HALBROOK R.S., SPARLING D.W., COLOMBO R. Metal accumulation and evaluation of effects in a freshwater Turtle. Ecotoxicology, 20, 1801, 2011.

34. TADISO T.M., BORGSTORM R., ROSSELAND B.O. Mercury concentrations are low in commercial fish species of Lake Ziway, Ethiopia, but stable isotope data indicated biomagnification. Ecotoxicology and Environmental Safety, 74 (4), 953, 2011.

35. CHATEAUVERT J. Influence of feeding ecology on mercury accumulation in turtles and fish of the Rideau Canal, Ontario, Canada. M. Sc thesis Ottawa-Carleton Institute of Biology, 111, 2013.

36. LANDLER L., PAINTER M.S., COE B.H., YOUMANS P.W., HOPKINS W.A., PHILLIPS J.B. High levels of maternally transferred mercury disrupt magnetic responses of snapping turtle hatchlings (Chelydra serpentina). Environmental Pollution 228, 19, 2017.

37. MALIK R.N., GHAFFAR B., HASHMI M.Z. Trace metal in Ganges soft-shell turtle (Aspideretes gangeticus) from two barrage: Baloki and Rasul, Pakistan. Environmental Science Pollution Research, 20, 8263, 2013.

38. CHIN S.Y., WILLSON J.D., CRISTOL D.A., DREWETT D.V.V., HOPKINS W.A. Altered behavior of neonatal northern water snakes (Nerodia sipedon) exposed to maternally transferred mercury. Environmental Pollution, 176, 144, 2013. 